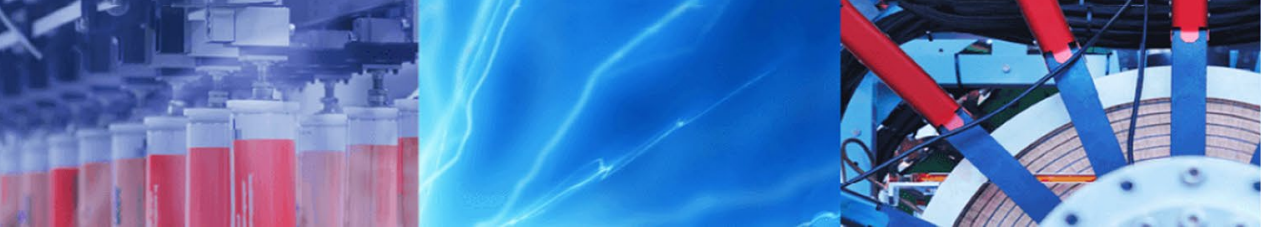

Research Article

\title{
Evaluating the variability, transport and periodicity of particulate matter over smart city Bhubaneswar, a tropical coastal station of eastern India
}

\author{
Saroj Kumar Sahu ${ }^{1}$ Bhishma Tyagi ${ }^{2} \cdot$ Chinmay Pradhan ${ }^{1} \cdot$ Gufran Beig $^{3}$
}

(c) Springer Nature Switzerland AG 2019, corrected publication 2019

\begin{abstract}
Air pollution has become a matter of concern over Indian mega-cities. In the present study, we analyse the variation of particulate matter (PM) $\left(\mathrm{PM}_{10}\right.$ and $\left.\mathrm{PM}_{2.5}\right)$ over Bhubaneswar $\left(20.18^{\circ} \mathrm{N}, 85.50^{\circ} \mathrm{E}, 45\right.$ above $\left.\mathrm{MSL}\right)$, which is a coastal Indian station, and the state capital of Odisha. Variation of meteorological parameters (i.e. air temperature, humidity, wind speed, and wind direction) over the station shows low winds originating and transported mainly from land areas during post-monsoon and winter, and from the Bay of Bengal during pre-monsoon and monsoon seasons. The site, in general, has evident diurnal variations of meteorological parameters and PM, other than monsoon season. In addition to surface observations at the site, 48-h back trajectory calculation by HYSPLIT model and the study employs potential source contribution function analysis for precise identification of the transported pollution areas for different seasons.
\end{abstract}

Keywords Particulate matter $\cdot$ Back trajectory $\cdot$ Potential source contribution function · Meteorological parameters

\section{Introduction}

Particulate matter (PM) is one of the critical pollutants responsible for the deprivation of human health, climate change, and acid rain $[1,7,22,27,36]$. It is also a critical pollutant responsible for deteriorating urban air quality [47]. The PM can be of natural origin, e.g. dust or volcanic eruption [50], or anthropogenic [29, 30]. The PM impacts (i.e. on human health) also depend on their size, with smaller particles more likely to penetrate deeper in lungs, and travel at greater distances [60]. The general distinction for $\mathrm{PM}$ categories comes as $\mathrm{PM}_{2.5}$ and $\mathrm{PM}_{10}$, where the 2.5 and 10 are the diameter size of the particles $[17,26,48]$. The pollution agencies of different countries in the world have fixed threshold values to decide the safe limits of PM for their regions, which varies for both $\mathrm{PM}_{2.5}$ and $\mathrm{PM}_{10}$. The $\mathrm{PM}_{2.5}$ and $\mathrm{PM}_{10}$ thresholds for daily values are $25 \mu \mathrm{g} \mathrm{m}^{-3}$ and $50 \mu \mathrm{g} \mathrm{m}^{-3}$ by World Health Organisation (WHO),
$35 \mu \mathrm{g} \mathrm{m}^{-3}$ and $150 \mu \mathrm{g} \mathrm{m}^{-3}$ by United States Environment Protection Agency (US EPA), and $60 \mathrm{\mu g} \mathrm{m}^{-3}$ and $100 \mathrm{\mu g} \mathrm{m}^{-3}$ by Central Pollution Control Board, India (CPCB) $[15,18]$.

Concentrations of $\mathrm{PM}$ over any region are varying diurnally as well as seasonally [16]. Usually, PM concentrations are found to be higher in winter season compared to rest of the year in densely populated tropical areas of the world (e.g. [41, 63]). The reasons for such a high load can be attributed to stable meteorological conditions with lower atmospheric temperatures, forcing lower heights of the mixed layer and supporting the accumulation of pollutants in a shallower boundary layer available for mixing [23]. Transported pollutants at any site may also increase the load of contaminants, and the source-apportionment studies are found to be useful for finding the regions, which are responsible for transported pollution to any location (e.g. $[25,40])$. This situation, however, may be different at coastal stations during the winter season, where

\footnotetext{
$\triangle$ Bhishma Tyagi, bhishmatyagi@gmail.com | ${ }^{1}$ P.G. Environment Sciences, Department of Botany, Utkal University, Bhubaneswar, India. ${ }^{2}$ Department of Earth and Atmospheric Sciences, National Institute of Technology Rourkela, Rourkela, India. ${ }^{3}$ Indian Institute of Tropical Meteorology, Pune, India.
} 
land-sea breeze interacts with the atmospheric boundary layer variation, and pollutants concentrations are changing during diurnal cycle (e.g. [2]). The sea breeze phenomena can enhance the pollutants concentrations along with winter season [42]. For examining the regional transport of PM, source apportionment emerges as a powerful tool (e.g. $[28,31,35])$. The method analyses the pollutant data in combination with wind data over any region to find the relative contributions of source locations at distance [20]. There are many approaches to source-apportionment techniques as well, with the most popular one as Potential Source Contribution Function (PSCF). The PSCF approach helps determine the receptor site concentrations where emissions from individual sources are not required [32]. The PM variations knowledge over any region (diurnal as well as seasonal) is essential to understand their impact on human health as well on weather and climate and to improve the prediction of air quality $[3,18]$.

In the present study, we have analysed the in situ data of $\mathrm{PM}_{2.5}$ and $\mathrm{PM}_{10}$ collected during 4 months: November 2016, January 2017, May 2017 and July 2017 at a tropical coastal Indian station, Bhubaneswar. The reason to select Bhubaneswar as the study site is its location due to its coastal nature and exposure due to its first smart city of India located in the eastern region. The East India experiences high pollution due to more than 15 large size coal-based power plants and many mineral and metal industries, where mainly coal is the primary source of energy [19]. The study aims to investigate the daily and seasonal variation of meteorological variables and PM, along with seasonal changes. Back trajectory analysis has been employed in the present study to gain qualitative knowledge about the wind approaching the measurement site. The PSCF analysis has been applied to understand the potential source areas during different seasons, contributing to the transported load of PM over the study region. The objectives of the present study are 1. Investigation of daily and seasonal variations of particulate matter pollution over the study region. 2 . The identification of the transported pollution and the identifications of main regions responsible for it with seasonal variation. 3 . Finding the existing periodicity in the time series of particulate matter data over the station.

\section{Site description, data, and methodology}

The study region is Bhubaneswar, a tropical coastal station with Bay of Bengal lying in the northeast to southwest directions, at a spatial distance of $\sim 66 \mathrm{~km}$ in South, and $\sim 96 \mathrm{~km}$ in East. The population for Bhubaneswar metropolitan area is 886,397 [5]. There are a total of 592,530 registered vehicles in March 2012 (328,395 two wheelers and
71,964 four wheelers), with rapid growth in two wheelers. The total length of the road network is $1498 \mathrm{~km}$ [37]. The city is experiencing rapid urbanisation $(83 \%$ increases in the 2000-2014 period) with $89 \%$ decrease in dense vegetation and $83 \%$ decrease in crop fields over this period [55]. The measurement site for the present study is on the campus of Utkal University $\left(20.18^{\circ} \mathrm{N}, 85.50^{\circ} \mathrm{E}, 45\right.$ above MSL) which is at the heart of Bhubaneswar, the first smartest city of India, and the capital of state Odisha, India. The smart city initiative adopts any particular city as a smart city in India if the city has core infrastructure and quality of life with a relatively clean and sustainable environment. The adopted smart city will be provided additional funds for sustainable and inclusive development and make the cities an ideal model for other aspiring cities [51].

The in situ data sets used in the present study have been collected under the Monitoring of Atmospheric Pollutants and Network MAPAN program, sponsored by the Ministry of Earth Science, Govt. of India. The site has an Air Quality Monitoring Station (AQMS) and Automatic Weather Station (AWS) for continuous monitoring of air pollutants and meteorological parameters. The data collected at the site have been utilised for the first time and are different than the earlier published works over Bhubaneswar [33], where the sites were at different locations to the present place of observation, which may be the reason for the lower values reported in the previous works.

The present study utilises hourly data sets of relative humidity, wind speed, wind direction, and air temperature. The hourly concentration values of $\mathrm{PM}_{10}, \mathrm{PM}_{2.5}$ (monitored using Environment S.A. optical analysers, model and make: EPQM-1013-211 for $\mathrm{PM}_{2.5}$, and EQPM-0404-151 for $\mathrm{PM}_{10}$ ) are available at the study site. The period of study includes the data sets for 4 months, i.e. November 2016, January 2017, May 2017, and July 2017, representing the post-monsoon, winter, pre-monsoon and monsoon seasons, respectively. There is missing data for meteorological parameters during November 2016 due to the technical issue with the weather station. All the data sets have been quality checked before analysing, and the details of the quality check are on SAFAR website (http://safar.tropm et.res.in). We also used the ERA-Interim reanalysis data sets [8] are also used for calculating boundary layer/mixed layer height (BLH) over Bhubaneswar.

The 2 days ( $48 \mathrm{~h}$ ) isentropic back trajectories were calculated at every $3 \mathrm{~h}$ using GDAS (Global Data Assimilation System) $1^{\circ}$ data sets by using NOAA (National Oceanic and Atmospheric Administration)-HYSPLIT (Hybrid Single Particle Lagrangian Integrated Trajectories) model [11-13, 45, 52]. Although GDAS $0.5^{\circ}$ data are also available, the vertical velocity is absent in GDAS $0.5^{\circ}$ data which results in better back trajectories computations by GDAS $1^{\circ}$ compared to GDAS $0.5^{\circ}$ data [54]. We used these calculated trajectories 
further in conjunction with PM data sets for calculation of potential source contribution function (PSCF) over the study period for identifying the spatial distribution of the transported pollution source regions. The details of PSCF methodology can be found at Han et al. [20], Gogikar and Tyagi [15] and Xu and Akhtar [61]. There are other methods (e.g. concentrated weighted trajectory-CWT) method equivalents to the PSCF, based on trajectory statistical methods. The ensemble average correlation coefficient study reveals that PSCF calculations are better than CWT [24] and motivates us to employ only PSCF in the present study.

Continuous wavelet transform (CWT) scalogram is a tool for determining dominant modes within a time series by decomposing the time series into the time-frequency domain $[44,56,62]$. In the present study, the periodicity test is performed on hourly data sets using Morlet mother wavelet, normalised by the standard deviation. Further mathematical details of Morlet wavelet and scalogram are available in Torrence and Compo [56].

\section{Results}

\subsection{Variation of meteorological parameters}

The variation of meteorological parameters (air temperature, relative humidity, wind speed, and wind direction) has been studied to understand the meteorological conditions over the study site. As mentioned in the data section, the meteorological observations were absent during
November 2016. The variation of parameters for January, May, and July 2017 is in Fig. 1. Figure 1a is showing the diurnal variation of temperature and humidity, averaged for the whole month of January 2017, while the wind rose diagram depicts the wind speed, and wind direction (all the values, without any average) (Fig. 1d) for the same month. The error bars in the figure are standard deviations of observations. Figure 1a infers that the temperature range is $\sim 12-33^{\circ} \mathrm{C}$, while the relative humidity was found to be highly variable ( 5-95\%) during January 2017 . The relative humidity and air temperature are having a perfect anti-correlation with the air temperature minimum at 6-7 A.M. in morning and maximum at 3-4 P.M. in the afternoon, while relative humidity minimum at 3-4 P.M. and maximum at 6-7 A.M. The humidity values are high during the night and early morning and low during the day, because of the land-sea breeze phenomenon. Wind roses (Fig. 1d) show that predominant directions are northeasterly and south-westerly with components of southerly, south-easterly, and north-westerly. It is to be noted here that wind speeds do not have significant difference during day or night over the study site during the study period (not shown). As mentioned in the site description, the place is a coastal station with Bay of Bengal lying in the northeast to southwest directions. Therefore, our surface winds are showing origination from land areas of Kolkata to marine nature few other times. This result enhances the possibility of transported pollution over the study region from the metropolitan city Kolkata during January.

Figure 1b, e is showing variation for May 2017 over the observational site. As can be observed from Fig. 1b, the
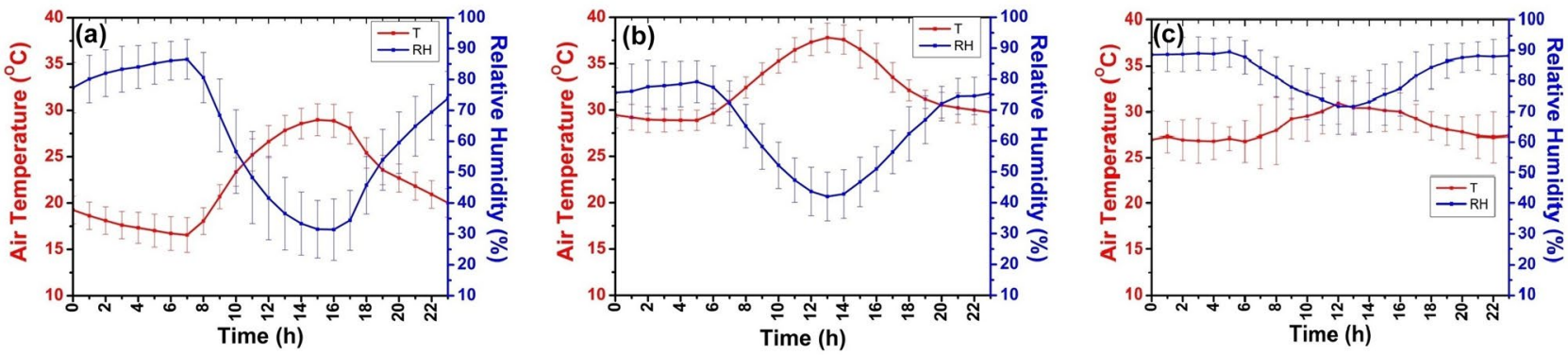

(d)

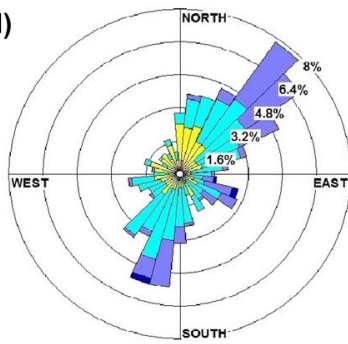

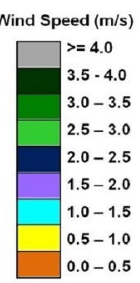

(e)

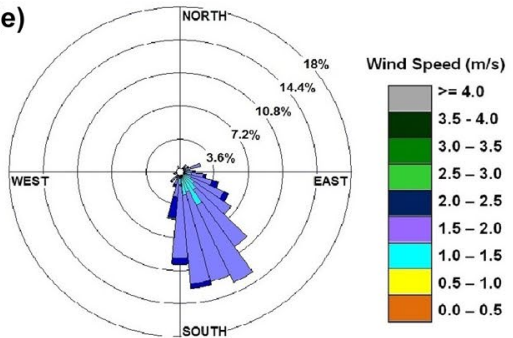

(f)

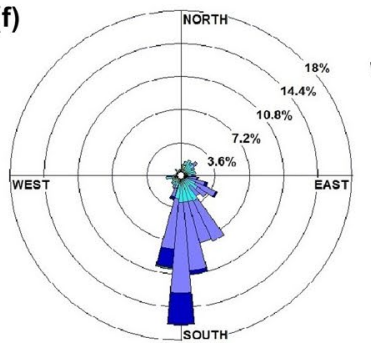

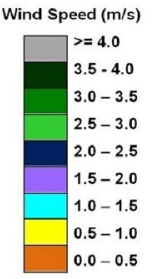

Fig. 1 Diurnal variation of air temperature and relative humidity a January, b May, and c July, and wind roses for $\mathbf{d}$ January, e May, and $\mathbf{f}$ July. The error bars in $\mathbf{a}-\mathbf{c}$ are standard deviations 
temperatures are high comparing to January with values $28-39^{\circ} \mathrm{C}$, and the humidity ranging from 28 to $80 \%$. May 2017, which comes in the pre-monsoon season, considered as one of the hottest months for the Bhubaneswar, and if we discriminate seasons as summer-winter-autumn-spring, comes in the summer season. Here also the perfect anti-correlation between temperature and relative humidity is apparent, which the predominant wind directions are south-easterly (Fig. 1e), with almost negligible components from other directions. The result shows that our surface winds are marine originated predominantly, limiting the possibility of transported pollution over the study region. For the monsoon month (July 2017), the air temperature and relative humidity variations (Fig. 1c) are showing the effect of rainfall over the study site. The air temperatures are varying between 24 and $34{ }^{\circ} \mathrm{C}$, and the humidity ranging from 75 to $95 \%$. The rainfall over Bhubaneswar is the second highest in July (with an average of $326.2 \mathrm{~mm}$ from 1901 to 2000), following the highest rainfall in August (with an average of $366.8 \mathrm{~mm}$ for a period of 1901-2000) (India Meteorology Department online report: http://www.imd.gov.in/section/climate/ climateimp.pdf). The surface winds are mainly southerly, with small components of south-southeast and southsouthwest, primarily arriving from the Bay of Bengal.

For better visualisations of the daily values variations, the daily averaged wind speed, wind direction, daily accumulated rainfall ( $24 \mathrm{~h}$ ) and boundary layer height (BLH) values are plotted and shown in Fig. 2. As mentioned earlier, the month of November 2016 is not having in situ observations of wind parameters. Figure $2 a$ is showing rainfall and BLH daily variations. There were only 4 days with rainfall during November 2016, and the BLH value was $740 \mathrm{~m}$ during 4th November 2016, second of the three consecutive rainfall days. The average monthly BLH values are $680 \mathrm{~m}$ for November 2016. For January 2017, the average wind speed varies from 0.1 to $2.1 \mathrm{~m} \mathrm{~s}^{-1}$, with the higher values during 10-14 January 2017. As understood from Fig. 1, the predominant wind directions are either northeasterly or south-westerly with components in other directions. The plot also reveals that high wind speed values during January 2017 are from north-westerly
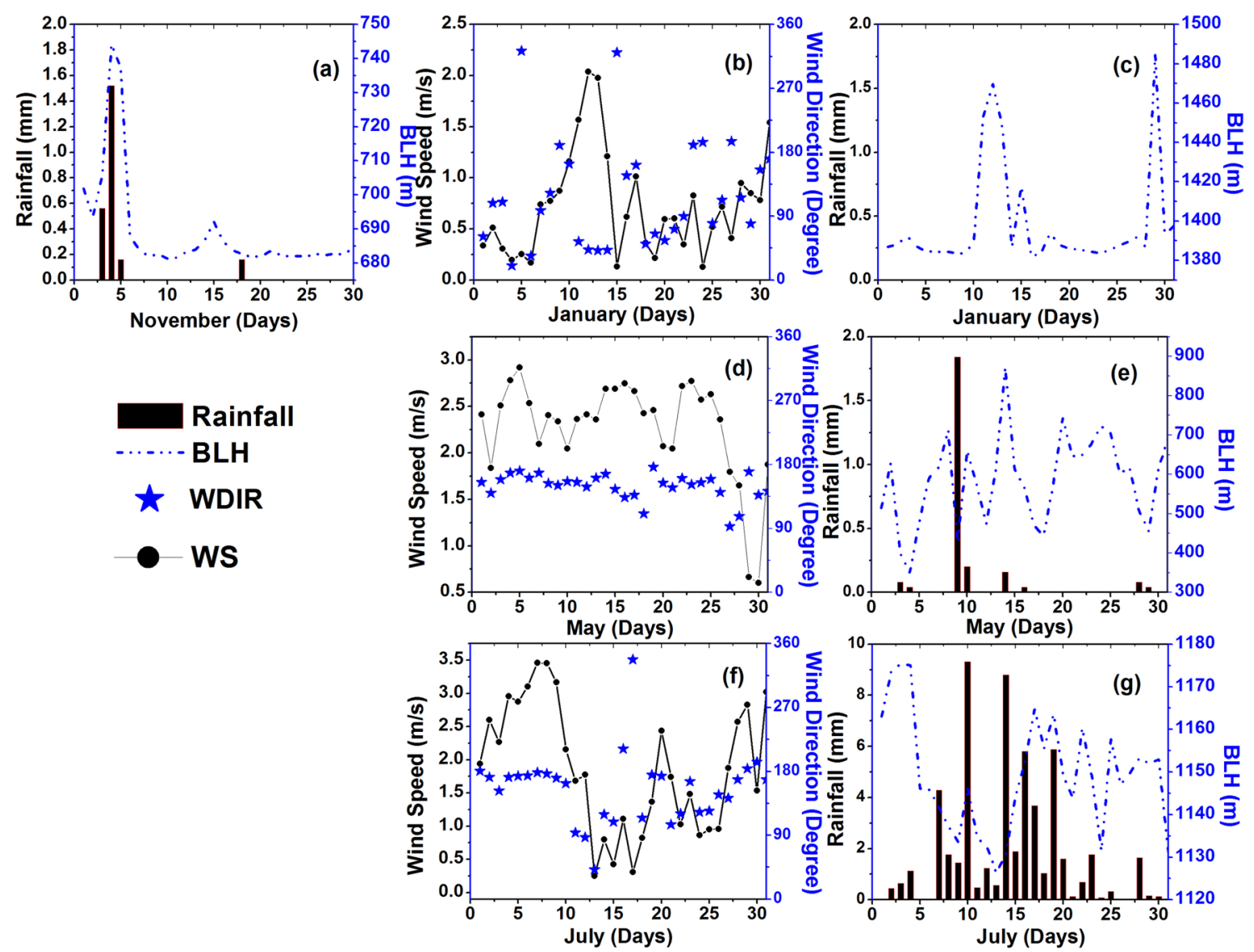

Fig. 2 Daily accumulated rainfall values and daily average values of boundary layer height for the months of a November 2016, c January 2017, e May 2017, and $\mathbf{g}$ July 2017. b, d, f Depicts the daily aver- age wind speed and wind direction variation for January, May, and July, respectively 
directions. There is no rainfall reported at the site during January 2017 (Fig. 2c), and the average BLH is $1398 \mathrm{~m}$. These high values of BLH during January month are characteristics of eastern Indian region with clear skies and no convective activity [6]. For May 2017, the average wind speeds are relatively high $\left(\sim 1.5-2.0 \mathrm{~m} \mathrm{~s}^{-1}\right)$, and the wind directions are south-easterly (Fig. 2d). During May, a total of eight rainy days occur. These rainfall events are due to pre-monsoon thunderstorms, which are the rainbearing system for this part of the country during this season $[57,58]$, and the average BLH is $587 \mathrm{~m}$ (Fig. 2e). July 2017 is one of the monsoon months at the site, and the daily average wind speed is fluctuating between 0.5 and $3.5 \mathrm{~m} \mathrm{~s}^{-1}$ with mostly south-easterly winds (Fig. 2f). There are 25 rainy days in the month with the varying amount of rainfall and BLH. However, the average BLH is 1149 m for July 2017, much higher than May 2017. The observations suggest that November and May are having less BLH so that concentrations may rise. However, the July month has frequent rainfall at the site, and there is a possibility of rainout and washout of PM for the period. The first week of November is likely to have fewer values of PM due to higher BLH associated with rainy days at the site.
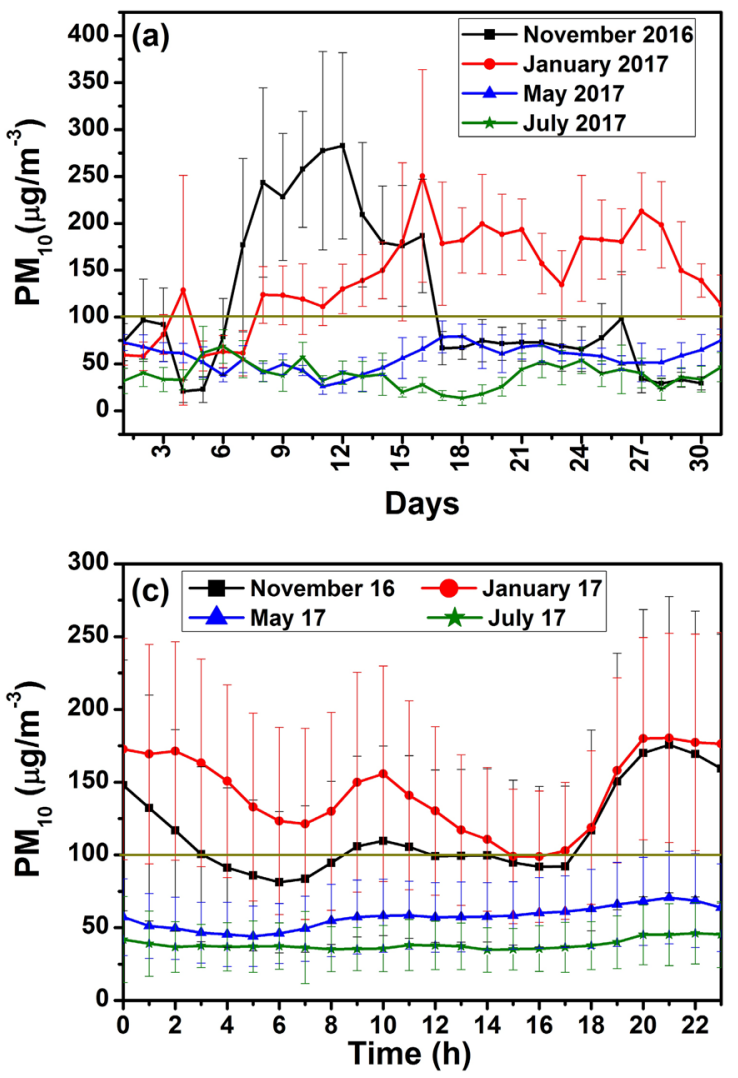

Fig. 3 Hourly variation of a $\mathrm{PM}_{10}$, b $\mathrm{PM}_{2.5}$, and averaged diurnal variation of $\mathbf{c} \mathrm{PM}_{10}$, d $\mathrm{PM}_{2.5}$ for November 2016, January 2017, May 2017, and July 2017. c, d The error bars are the standard deviation.
To validate the findings of meteorological observations, the diurnal variation of PM is analysed in the next section.

\subsection{Diurnal variation of $\mathrm{PM}_{10}$ and $\mathrm{PM}_{2.5}$}

The daily time series plots of $\mathrm{PM}_{10}$ and $\mathrm{PM}_{2.5}$ (Fig. 3a, b), and the averaged diurnal variation of $\mathrm{PM}_{10}$ and $\mathrm{PM}_{2.5}$ (Fig. 3c, d), for all the months are showing the difference in magnitudes. The specified threshold limit by CPCB for $\mathrm{PM}_{10}$ (i.e. $100 \mu \mathrm{g} \mathrm{m}^{-3}$ ) and $\mathrm{PM}_{2.5}$ (i.e. $60 \mu \mathrm{g} \mathrm{m}^{-3}$ ) has been marked by the dark yellow line in Fig. $3 a-d . P_{10}$ and $P_{2.5}$ hourly variations are showing that for November 2016, the initial days (01-06) are occasionally crossing the threshold values, while the mid of the month (from 07 to 16 ) is experiencing high concentrations. At the end of November (from 17 to 30 ), the PM concentrations are again going below threshold limits. The elevated values of PM from 07 to 16 November are crossing the suggested daily threshold limits for the site. The cause of such high concentrations will be investigated by employing the back trajectory analysis in the next section. In January 2017, the values were below the threshold limit during the first week for $\mathrm{PM}_{10}$ and from 01 to 16 January for $\mathrm{PM}_{2.5}$.
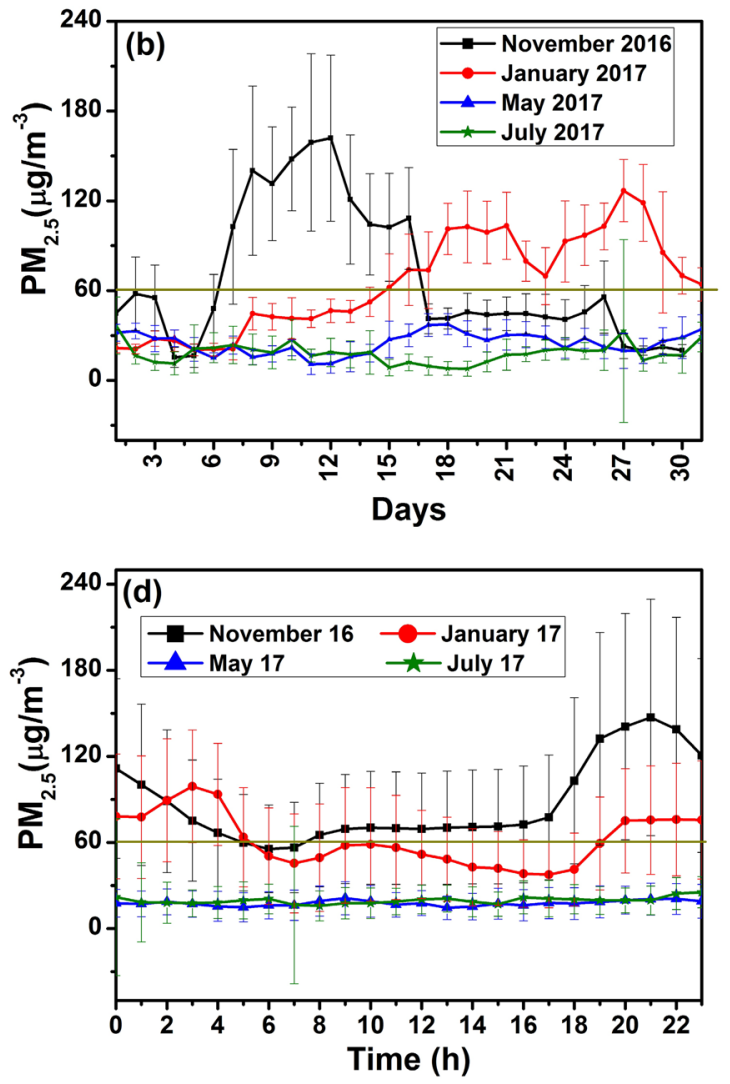

The solid cyan line in $\mathbf{a}-\mathbf{d}$ is depicting the specified threshold limit by $C P C B$ for $\mathrm{PM}_{10}$ (i.e. $100 \mu \mathrm{g} \mathrm{m}^{-3}$ ) and $\mathrm{PM}_{2.5}$ (i.e. $60 \mu \mathrm{g} \mathrm{m}^{-3}$ ) 
The surface winds analysis for the study period revealed that during 01-11 January, the winds are mostly southeasterly, which are of marine origin and not bringing any transported pollution. From 12 to 31 January, however, the predominant winds are either from North-Eastern or South-Western, both of land-origin and there is a chance of bringing transported pollutants over the region. In May 2017, the PM values are well below threshold, which can be explained by transportation of clear air from the Bay of Bengal transported to the site (as surface wind direction is south-easterly), and occasionally rainfall associated with thunderstorm over the study area during the month [38]. As mentioned in the previous section, July is the month of highest rainfall at the site, and the low values of PM are justified with washout of pollutants by rain, and prevailing surface wind direction being southerly (coming from the Bay of Bengal), bringing almost no transported pollution load over the site.

The examination of diurnal variation of PM (Fig. 3c, d) allows us to understand that the variational patterns are existing for November and January only, while the May and July are not showing variations and are more or less constant throughout the day. $\mathrm{PM}_{10}$ diurnal variations (Fig. 3c) are showing two maxima (at 9-11 and 20-23) and two minima ( 7 and $15-17$ ) for January and November (with less magnitude compared to January). $\mathrm{PM}_{2.5}$ diurnal variations (Fig. $3 \mathrm{~d}$ ) are also following the pattern of maxima and minima as that of $\mathrm{PM}_{10}$ only with a difference that in-between hour is having fewer variations in the values. The bimodal pattern is similar to that as observed over Beijing [31] and New York City [9], and many other sites globally [34]. The reason for such bimodal pattern is usually boundary layer height variation and daily emission patterns along with local meteorological cycles [34].

The diurnal boundary layer development over any region plays a vital role in the daily variations of PM. The height of boundary layer and its different sections during daytime (i.e. surface layer, mixed layer) and nighttime (i.e. stable layer and residual layer) are depending on the solar radiation and winds for generating turbulence in order to maintain the growth and development of boundary layer $[31,53]$. The resulting boundary layer height with stability regimes provides the depth of atmosphere available for the mixing of pollutants, e.g. PM in the present study. The morning maxima may be explained about enhanced traffic and anthropogenic activities during office hours, while the evening maxima are related to the traffic emissions linked with changes in the height of the boundary layer. The morning minima are the time when the nighttime stable boundary layer is transforming into the daytime mixed layer. The second minima during afternoon hours are the period when the mixed layer height will be the highest over the study region in November and January.

\subsection{Back trajectory and cluster analysis}

The back trajectory analysis for $48 \mathrm{~h}$ (i.e. 2 days) has been computed for the study period, along with cluster analysis based on Euclidean distance (Fig. 4). The transported air-masses are from both land and sea origin reaching to the site during different months of the study period. During November 2016 (i.e. post-monsoon season), the
Fig. 4 48-h back trajectory analysis for post-monsoon (November) (black colour), winter (January) (red colour), pre-monsoon (May) (green colour), and monsoon (July) (blue colour). The yellow star marks the site location, and the thick line is depicting clusters based on Euclidean distance for each month

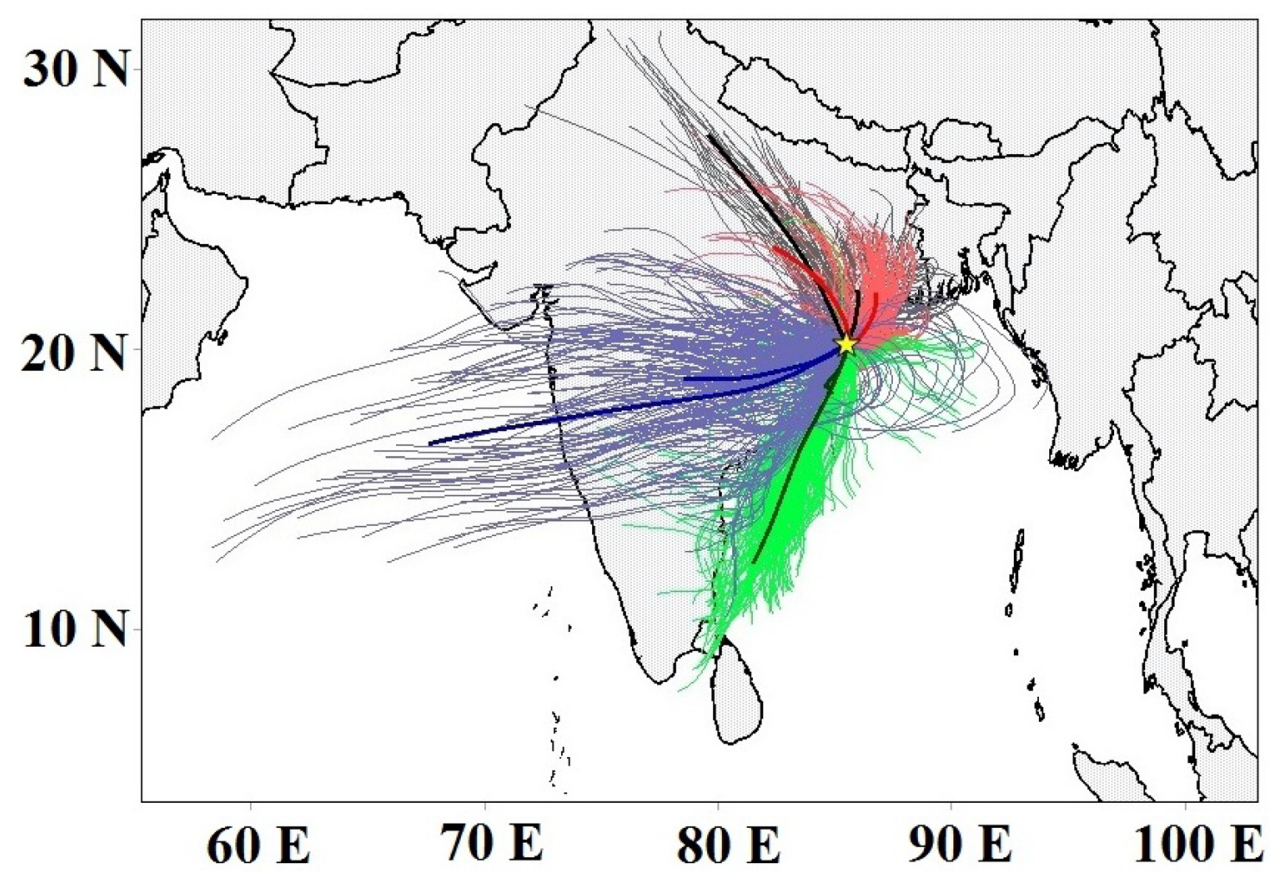


air-masses are approaching the study site mainly from north to north-north-west directions, bringing the polluted air of Indo-Gangetic plains. The cluster analysis for November is indicating that two types of air-masses are primarily approaching the site, one from the Northern part of India from the states of Uttar Pradesh and capital city Delhi, and the other one from the West Bengal area. To understand the higher values of 07-16 November 2016, the back trajectory analysis for these days in comparison with other days of November shows no difference in the place of origin. As the residence time of PM is variable depending on the associated meteorological variations and can be from 1 day to 2 weeks or more [10], the high pollution levels during 07-16 November may be the result of transported pollution over the region. The higher values may be due to highly polluted and turbid atmosphere over Indo-Gangetic plains during the festival deepawali/diwali which was on 30 October 2016, and associated other festivals of same period ending in first week of November 2016 $[43,46,49]$. Here, it must be noted that the Bhubaneswar city is also having the celebration of fireworks during the festival and the pollution levels from local contribution are also on the higher side as well as for the transported pollution. This transported pollution will have a support of the stable atmosphere due to winter onset, and relatively lower heights of the boundary layer during the November, which result in enhancing the levels above the threshold limits.

In January 2017 (winter season) also, the air-masses from the Indo-Gangetic plain are approaching the site. The clusters are indicating, however, that air-masses are not coming as far as they were in case of November, and mainly originating from neighbouring states of Jharkhand, West Bengal, and Chhattisgarh, indicating the low-wind speeds during the winter conditions. Results also show that even the BLH is high, local emission of pollutants with transported pollutants from the areas are making the PM levels above the threshold limits. The interesting observation to note here is that during first 10 days of January, where the PM levels are below threshold levels, the airmasses are coming from the Bay of Bengal (marine origin) (figure not shown here). The result indicates that if the transported air-masses are clean, the PM levels are well below threshold even during the winter conditions. For the summer/pre-monsoon month (May 2017), the air-masses approaching the site are mainly marine, bringing clean air to the area. This clean transported air provides a more extensive region for mixing available to locally generated pollution, which results in PM values well below thresholds throughout the month. As mentioned earlier, the site is also experiencing occasionally rain showers associated with thunderstorms [38], which will also help in washout of PM during May. When we perform the back trajectory analysis for the monsoon month (July), we found that the air-masses are coming from the parts of central India to western India, originating from the Arabian Sea side. This behaviour of Arabian Sea side winds reaching to the area is well understood under the monsoon studies [39], and undoubtedly the clean marine air, and sufficient rain during the month may be the reason for the low values of PM observed over the site during July. The percentage-wise height variation of these trajectories shows that $\sim 50 \%$ of the trajectories are below $500 \mathrm{~m}, 82.7 \%$ are below $1 \mathrm{~km}$, and rest crossed the $1 \mathrm{~km}$ height but lay below $2 \mathrm{~km}$, and also the trajectories which are coming from the identified source areas of higher contribution are always less than $1 \mathrm{~km}$ height. Thus, they are valid for representing pollution transportation at the site.

\subsection{Source-receptor modelling of $\mathrm{PM}_{10}$ and $\mathrm{PM}_{2.5}$}

For the identification of source regions and their relative contribution to the transported concentration of PM, the PSCF technique has employed in the present study. Figure 5 shows the PSCF analysis for chosen months representing four different seasons for $\mathrm{PM}_{10}$. The legend is showing normalised weighted potential source contribution factor. Here we are not showing PSCF analysis for $\mathrm{PM}_{2.5}$, as for both $\mathrm{PM}_{10}$ and $\mathrm{PM}_{2.5}$, the source regions are found to be the same by PSCF analysis for all the four seasons.

For the post-monsoon season (i.e. November 2016), the PSCF analysis shows (Fig. 5a) the transport from the Indo-Gangetic plain and adjoining areas. However, the significant contributions are mainly from the northeast and northwest sectors from the neighbouring states of Jharkhand and West Bengal with the possible accounting of mineral and exploration belts of Jharkhand [14], and influence of Metropolitan city Kolkata of West Bengal [46]. Figure 5 a shows that $>50 \%$ contribution is from transported pollution. In the winter season (January 2017), the PSCF extent is broadly over the same areas that for November 2016 (Fig. 5b), but the prime regions contributing to the transported pollutions shifted towards the north of the observational site, i.e. towards Kolkata and adjoining areas of West Bengal, which accounts $>70 \%$ pollution. The marine nature of transported air is also visible in the PSCF analysis, but the larger extent is visible from the northerly direction, mainly coming from the Metropolitan city of Kolkata to the site. Here the higher BLH is also not able to reduce the concentrations for January 2017, and indicating that transported pollutants are playing an important role in elevating the concentration levels. In the case of pre-monsoon season (May 2017), as the trajectory analysis indicates, the natures of transported air-masses are of mainly marine origin (Fig. 5c). The PSCF analysis traces the 

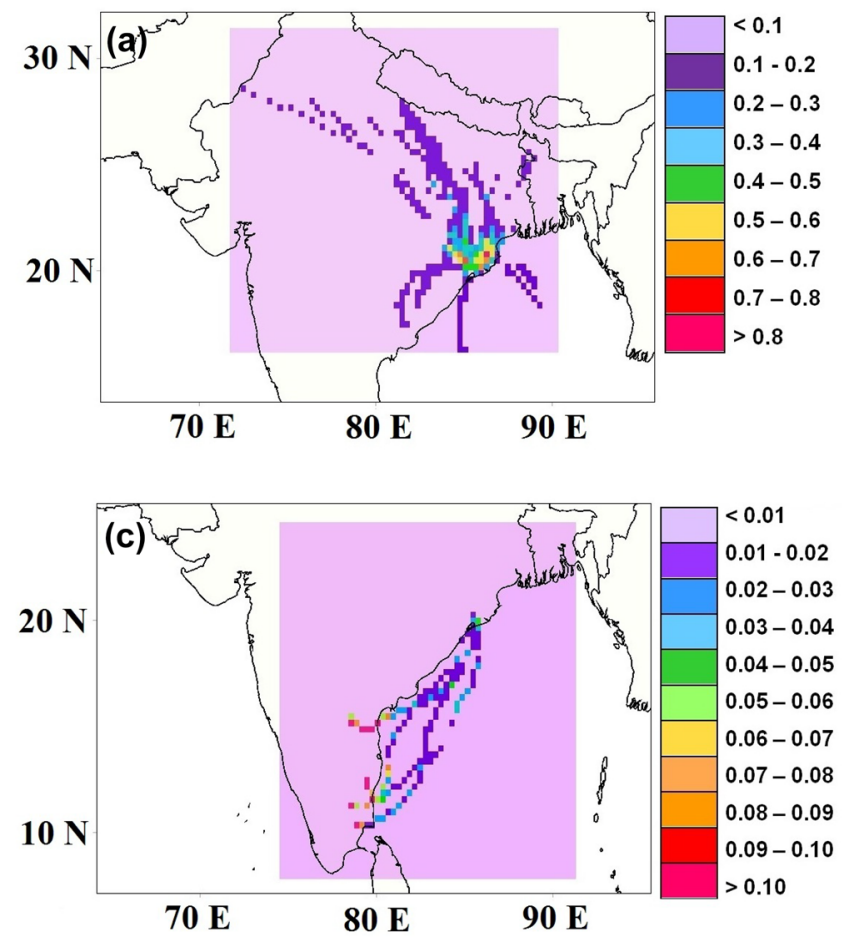
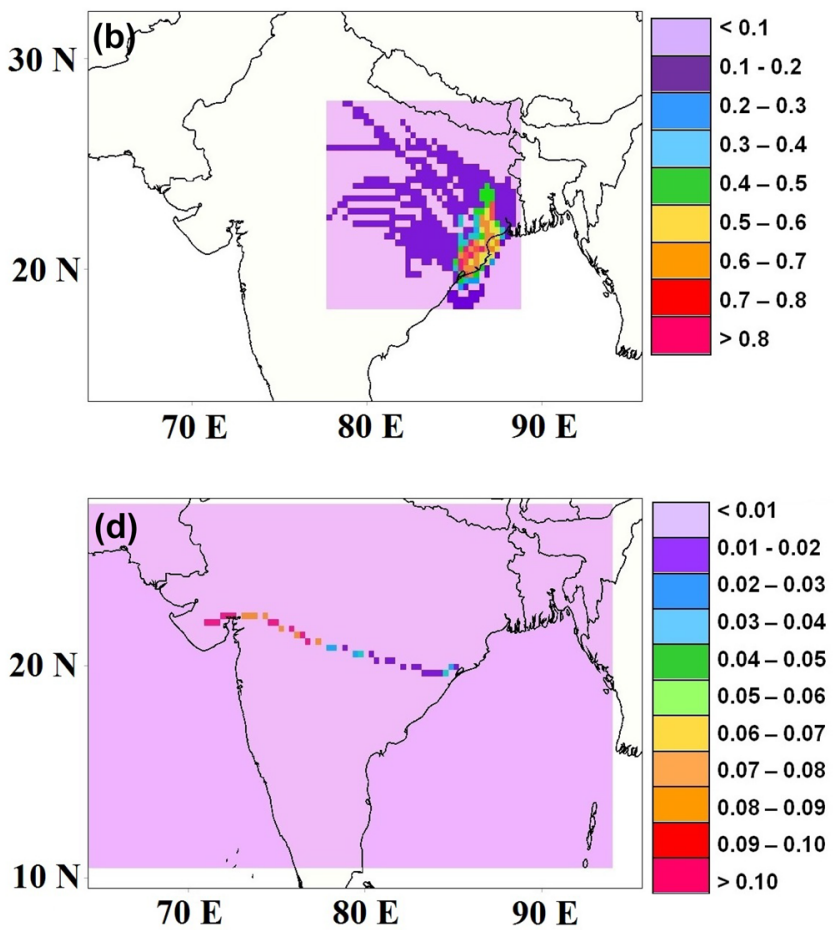

Fig. 5 Source-receptor modelling of PM for a post-monsoon (November), b winter (January), c pre-monsoon (May), and d monsoon (July)

land origination of air-masses and showing the region of coastal Andhra Pradesh, and Tamil Nadu states as the source regions to the transported PM concentration over the site. It is proving the efficiency of the PSCF analysis as it did not choose the potential contribution from the Bay of Bengal at any point in this case of the summer month. PSCF identifies the high polluted coastal region impact and the nature of transported pollution can distinguish the land and sea regions in contributing the pollution. The results are also advocating that even though BLH values are low for May, the pollutions levels are not crossing the threshold, and hence the impact of transported pollution is critically affecting the pollution levels of the city, rather than the local emissions, which are present on a day-today basis.

During monsoon month of July 2017 (Fig. 5d), the PSCF analysis is identifying significant contributions from the land regions up to the western extent of India (i.e. in the state of Gujarat). But, the scale of these considerable contributions is relatively smaller as compared to the other months analysed, and the broad areal extent is quite large, as we are receiving air-masses from a vast domain (Fig. 4). The PSCF analysis shows that the limits of contributing areas are far more extendable towards land regions in Indo-Gangetic plain areas, with little contribution from the Bay of Bengal region. As we can see from Fig. 5, the seasonal variation is indicating that during November and January there is $\sim 20 \%$ source contribution coming from the marine side, which reduced to $\sim 5 \%$ during May, and $<1 \%$ in July. The analysis shows that not only locally generated pollution is adding in the aerosol load over the site, but transported pollutants are also having a pivotal role in taking higher concentrations over the study region. However, the results impaired with the limitation of the method to adequately capture the sources due to rainout/ washout processes occur during the monsoon. The result for July month is therefore not showing specific findings in the present study.

\subsection{Continuous wavelet transform (CWT) analysis}

The CWT analysis is employed in the current work for understanding the change in different frequencies from the aerosol number concentration over time for $\mathrm{PM}_{10}$ and $\mathrm{PM}_{2.5}$ (Figs. 6, 7). The CWT scalogram is a representation on the time-scale domain, where each coefficient is plotted by the gradient, corresponding to the magnitude of the coefficient. The existence of a peak in the scalogram for time series of the PM indicates that a high-frequency component is present in the series.

Figure 6 shows the wavelet scalogram analysis of the hourly aerosol number concentration time series relating to the starting hour of the month to the ending hour of the month for $\mathrm{PM}_{10}$. The abscissa is representing the time expressed in hours from the beginning of the month (i.e. from 01 to $23 \mathrm{~h}$ for 1-30 November 2016 in Fig. 6a, 1-31 

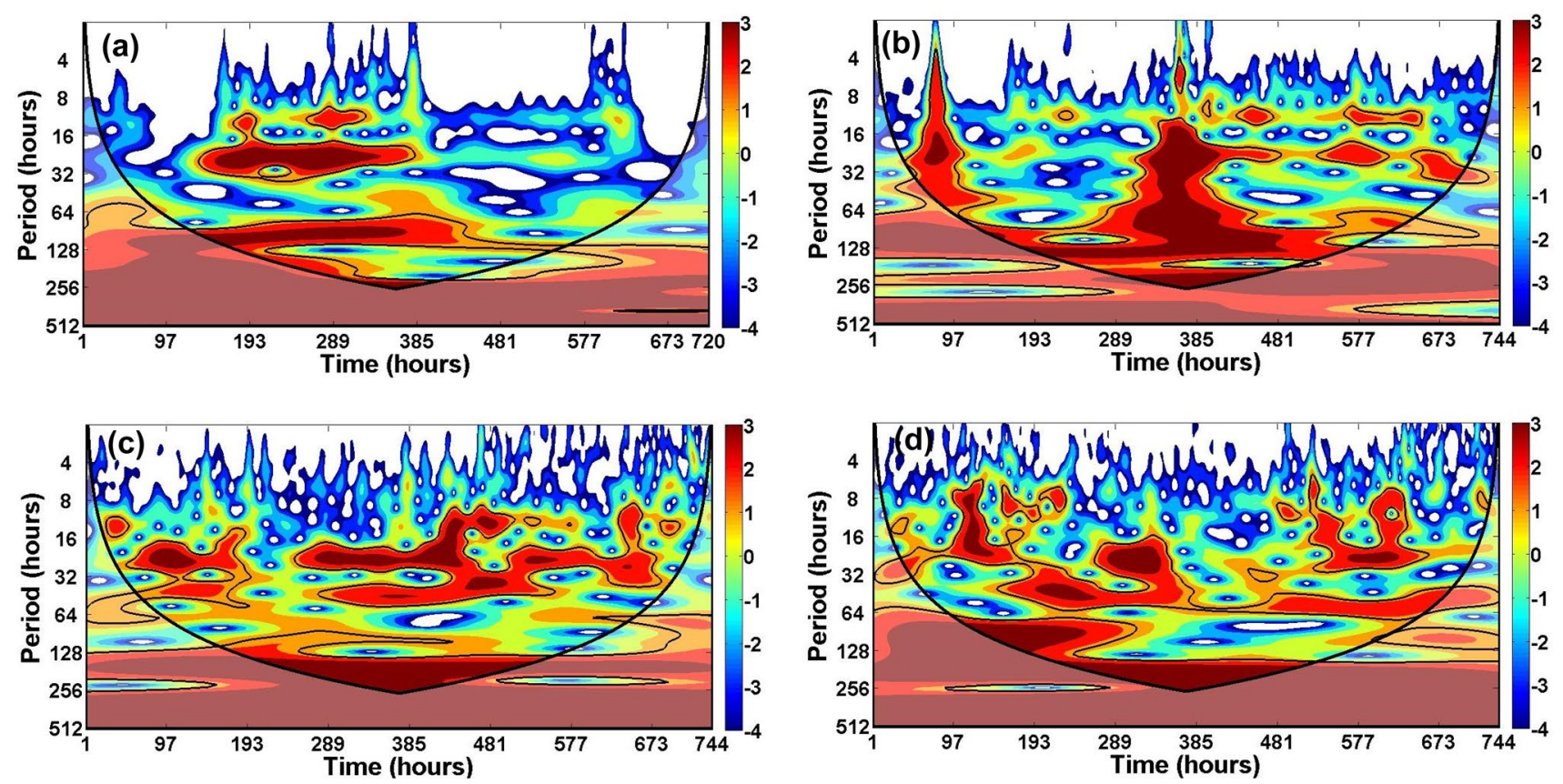

Fig. 6 Periodicity analysis in $\mathrm{PM}_{10}$ variation for a post-monsoon (November), b winter (January), c pre-monsoon (May), and d monsoon (July)
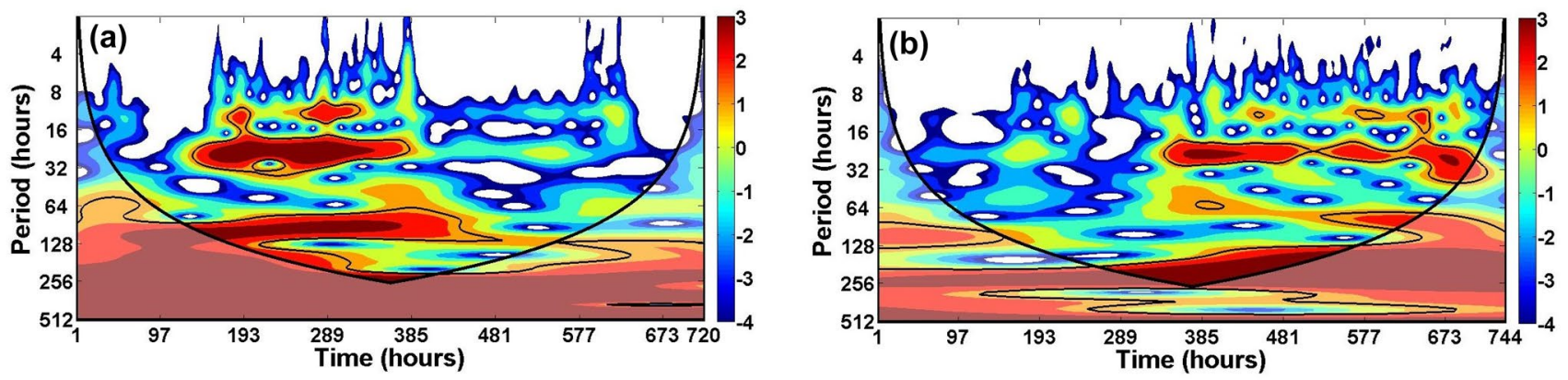

(c)

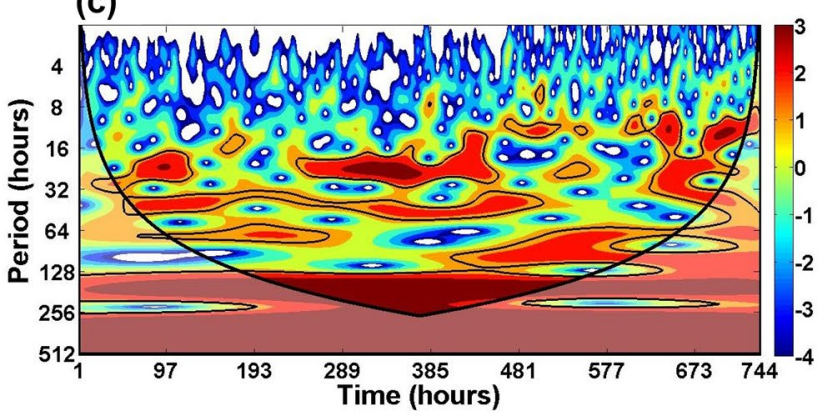

(d)

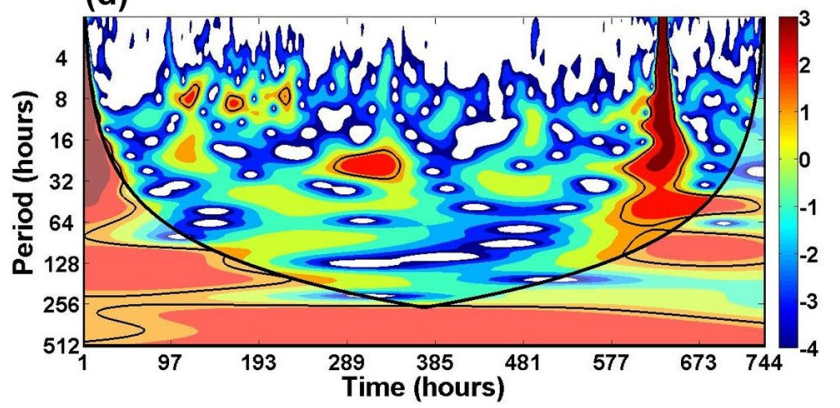

Fig. 7 Periodicity analysis in $\mathrm{PM}_{2.5}$ variation for a post-monsoon (November), b winter (January), c pre-monsoon (May), and d monsoon (July)

January 2017 in Fig. 6b, 1-31 May 2017 in Fig. 6c and 1-31 July 2017 in Fig. 6d), and the ordinate is depicting the time scale ranging from 1 to $512 \mathrm{~h}$. The thick black line in the shape of a middle bracket is known as the cone of influence, below which the analysis is masked and not considered because of its interference with noise. In November 2016 (Fig. 6a), the prominent feature of $\mathrm{PM}_{10}$ data is 5 days $(\sim 120 \mathrm{~h})$ periodicity. Another noticeable periodicity is visible at $16-32 \mathrm{~h}$, corresponding to a daily cycle between 4 and 13 November 2016 . 
These regular periodicities along with semi-diurnal and 5-day periodicities are observed in January 2017 as well (Fig. 6b), with definite localisations found in the initial and mid-month data sets. The pre-monsoon, i.e. May 2017, month (Fig. 6c) is also having a clear indication of daily, 2-day and 5-day periodicities included in the variations of $\mathrm{PM}_{10}$ concentrations. Even in July 2017 (the monsoon month), there is evidence of 2-5-day periodicity (Fig. 6d). However, on the smaller side of the range $(2-16)$, the localisation of periodicity is more evident at 97-193 h (05-08 July), and 577-673 h (24-28 July). When we analysed the periodicity associated with $\mathrm{PM}_{2.5}$ (Fig. 7), we observe the daily and 5-day periodicity in November (Fig. 7a), January (Fig. 7b), and May (Fig. 7c). However, during the monsoon month of July, there is no such observed periodicity (Fig. 7d).

The daily cycle can be a result of as locally generated pollution during rush hours [21], whereas 5-day cyclic period can be understood synoptic-scale period where atmospheric high- and low-pressure systems interchange [4]. The observed dominant frequencies can be connected with quasi-cyclic meteorological processes, as the synoptic processes with periods between 8 and 11 days may be the cause of observed periodicities in the $\mathrm{PM}_{10}$ variations [59].

\section{Summary}

Analysis of the $\mathrm{PM}_{10}$ and $\mathrm{PM}_{2.5}$ hourly concentrations for the months in different seasons during period 2016-2017 showed that levels are higher in January (winter season) followed by post-monsoon (November), pre-monsoon (May), and monsoon (July) with least concentrations. We can summaries the findings as follows:

- The bimodal distribution pattern is observed in the diurnal variation of $\mathrm{PM}_{10}$, while $\mathrm{PM}_{2.5}$ is showing one peak (in the night time for November and early morning in January) only.

- The back trajectory and PSCF analysis showed that during January, pollution transportation is significant and the metropolitan city of Kolkata and adjoining areas are the main contributors in the transported PM levels at the study area. The transported pollution is having its contribution in the post-monsoon season (November) as well, but during pre-monsoon and monsoon season, the concentrations levels are mainly because of local emissions.

- The PM variations over different months have periodicity involved in their distribution, with dominant visible periods of daily ( 1 day) and 5-day scales.
Acknowledgements Authors want to acknowledge the Indian Institute of Tropical Meteorology (IITM), Ministry of Earth Science, Govt. of India, for funding the instrumented site under MAPAN program (Grant No. MoES/Indo-Nor/PS-10/2015). We want to thank HYSPLIT development team for providing the model and National Center for Environmental Prediction (NCEP) for the GDAS data. Authors are thankful to the European Centre for Medium-Range Weather Forecast (ECMWF) for providing ERA-Interim reanalysis data sets.

\section{Compliance with ethical standards}

Conflict of interest On behalf of all authors, the corresponding author states that there is no conflict of interest.

\section{References}

1. Balakrishnan K, Dey S, Gupta T, Dhaliwal RS, Brauer M, Cohen AJ, Stanaway JD, Beig G, Joshi TK, Aggarwal AN, Sabde Y (2019) The impact of air pollution on deaths, disease burden, and life expectancy across the states of India: the Global Burden of Disease Study 2017. Lancet Planet Health 3(1):e26-e39

2. Bouchlaghem K, Nsom B, Lattrache N, Haj H (2008) Characterization of sea breezes and their effects on Air Pollution in the Tunisian Mediterranean region. In: Nikolinakou MK, Tsekouras G, Gekas V, Pavlou D (eds) Proceedings of the WSEAS international conference on mathematics and computers in science and engineering. WSEAS, Dallas

3. Bowe B, Xie Y, Li T, Yan Y, Xian H, Al-Aly Z (2018) The 2016 global and national burden of diabetes mellitus attributable to PM 2 . 5 air pollution. Lancet Planet Health 2(7):e301-e312

4. Byčenkienè S, Ulevicius V, Prokopčiuk N, Jasinevičienè D (2013) Observations of the aerosol particle number concentration in the marine boundary layer over the south-eastern Baltic Sea. Oceanologia 55(3):573-597

5. Census (2011) The Registrar General and Census Commissioner, India. http://www.censusindia.gov.in/2011 census/population _enumeration.html. Accessed 20 Feb 2019

6. Chandra S, Dwivedi AK, Kumar M (2014) Characterization of the atmospheric boundary layer from radiosonde observations along eastern end of monsoon trough of India. J Earth Syst Sci 123(6):1233-1240

7. Cohen AJ, Brauer M, Burnett R, Anderson HR, Frostad J, Estep K, Balakrishnan K, Brunekreef B, Dandona L, Dandona R, Feigin V (2017) Estimates and 25-year trends of the global burden of disease attributable to ambient air pollution: an analysis of data from the Global Burden of Diseases Study 2015. Lancet 389(10082):1907-1918

8. Dee DP, Uppala SM, Simmons AJ, Berrisford P, Poli P, Kobayashi $S$, Andrae U, Balmaseda MA, Balsamo G, Bauer P, Bechtold P, Beljaars ACM, van de Berg L, Bidlot J, Bormann N, Delsol C, Dragani R, Fuentes M, Geer AJ, Haimberger L, Healy SB, Hersbach $\mathrm{H}$, Hólm EV, Isaksen L, Kållberg $\mathrm{P}$, Köhler M, Matricardi $M$, McNally AP, Monge-Sanz BM, Morcrette J-J, Park B-K, Peubey C, de Rosnay P, Tavolato C, Thépaut J-N, Vitart F (2011) The ERAInterim reanalysis: configuration and performance of the data assimilation system. Q J R Meteorol Soc 137:553-597. https:// doi.org/10.1002/qj.828

9. DeGaetano AT, Doherty OM (2004) Temporal, spatial and meteorological variations in hourly PM2.5 concentration extremes in New York City. Atmos Environ 38:1547-1558

10. Długosz-Lisiecka M, Bem H (2012) Determination of the mean aerosol residence times in the atmosphere and additional 210 po input on the base of simultaneous determination of $7 \mathrm{be}$, 
22na, 210pb, 210bi and 210po in urban air. J Radioanal Nucl Chem 293(1):135-140

11. Draxler RR (1999) HYSPLIT4 user's guide. NOAA Technical Memorandum ERL ARL-230. NOAA Air Resources Laboratory, Silver Spring

12. Draxler RR, Hess GD (1997) Description of the HYSPLIT 4 modeling system. NOAA technical memo. ERL ARL-224. NOAA Air Resources Laboratory, Silver Spring, p 24

13. Draxler RR, Hess GD (1998) An overview of the HYSPLIT_4 modeling system for trajectories, dispersion, and deposition. Aust Meteorol Mag 47:295-308

14. Garg A, Shukla PR, Bhattacharya S, Dadhwal VK (2001) Subregion (district) and sector level $\mathrm{SO}_{2}$ and NOx emissions for India: assessment of inventories and mitigation flexibility. Atmos Environ 35:703-713

15. Gogikar P, Tyagi B (2016) Assessment of particulate matter variation during 2011-2015 over a tropical station Agra, India. Atmos Environ 147:11-21

16. Gogikar P, Tyagi B, Gorai AK (2019) Seasonal prediction of particulate matter over the steel city of India using neural network models. Model Earth Syst Environ 5:227-243

17. Gogikar P, Tyagi B, Padhan RR, Mahaling M (2018) Particulate matter assessment using in situ observations from 2009 to 2014 over an industrial region of eastern India. Earth Syst Environ 2(2):305-322

18. Guerreiro CBB, Foltescu V, de Leeuw F (2014) Air quality status and trends in Europe. Atmos Environ 98:376-384

19. Guttikunda SK, Jawahar P (2014) Atmospheric emissions and pollution from the coal-fired thermal power plants in India. Atmos Environ 92:449-460

20. Han YJ, Holsen TM, Hopke PK (2007) Estimation of source locations of total gaseous mercury measured in New York State using trajectory based models. Atmos Environ 41:6033-6047

21. Hirst JM (1953) Changes in atmospheric spore content: diurnal periodicity and the effects of weather. Trans Br Mycol Soc 36(4):375-393

22. Hu H, Landrigan PJ, Fuller R, Lim SS, Murray CJ (2018) New Initiative aims at expanding Global Burden of Disease estimates for pollution and climate. Lancet Planet Health 2(10):e415-e416

23. Jacobson MZ (2012) Air pollution and global warming: history, science, and solutions. Cambridge University Press, Cambridge

24. Kabashnikov VP, Chaikovsky AP, Kucsera TL, Metelskaya NS (2011) Estimated accuracy of three common trajectory statistical methods. Atmos Environ 45:5425-5430

25. Kalaiarasan G, Balakrishnan RM, Sethunath NA, Manoharan S (2017) Source apportionment of PM2.5 particles: influence of outdoor particles on indoor environment of schools using chemical mass balance. Aerosol Air Qual Res 17(2):616-625

26. Kim KH, Kabir E, Kabir S (2015) A review on the human health impact of airborne particulate matter. Environ Int 74:136-143

27. Kleinman MT, Phalen RF, Mautz WJ, Mannix RC, McClure TR, Crocker TT (1989) Health effects of acid aerosols formed by atmospheric mixtures. Environ Health Perspect 79:137-145

28. Kotchenruther RA (2016) Source apportionment of PM 2.5 at multiple Northwest US sites: assessing regional winter wood smoke impacts from residential wood combustion. Atmos Environ 142:210-219

29. Latha R, Murthy BS, Kumar M, Jyotsna S, Lipi K, Pandithurai G, Mahanti NC (2014) Aerosol optical properties and composition over a table top complex mining area in a monsoon trough region. Aerosol Air Quality Res 14(3):806-817

30. Latha R, Murthy BS, Kumar M, Lipi K, Jyotsna S (2013) Aerosol radiative forcing controls: Results from an Indian table-top mining region. Atmos Environ 81:687-694

31. Liu Z, Hu B, Wang L, Wu F, Gao W, Wang Y (2015) Seasonal and diurnal variation in particulate matter (PM10 and PM2. 5) at an urban site of Beijing: analyses from a 9-year study. Environ Sci Pollut Res 22(1):627-642

32. Lynam MM, Keeler GJ (2006) Source-receptor relationships for atmospheric mercury in urban Detroit, Michigan. Atmos Environ 40(17):3144-3155

33. Mahapatra PS, Sinha PR, Boopathy R, Das T, Mohanty S, Sahu SC, Gurjar BR (2018) Seasonal progression of atmospheric particulate matter over an urban coastal region in peninsular India: role of local meteorology and long-range transport. Atmos Res 199:145-158

34. Manning MI, Martin RV, Hasenkopf C, Flasher J, Li C (2018) Diurnal patterns in global fine particulate matter concentration. Environ Sci Technol Lett 5(11):687-691

35. Masiol M, Hopke PK, Felton HD, Frank BP, Rattigan OV, Wurth MJ, LaDuke GH (2017) Analysis of major air pollutants and submicron particles in New York City and Long Island. Atmos Environ 148:203-214

36. Menon S, Koch D, Beig G, Sahu S, Fasullo J, Orlikowski D (2010) Black carbon aerosols and the third polar ice cap. Atmos Chem Phys 10:4559-4571. https://doi.org/10.5194/ acp-10-4559-2010

37. Ministry of Urban Development (2019) http://utbenchmark.in/ UsersidePages/CityProfile.aspx?City=2. Accessed 20 Feb 2019

38. Mohanty UC et al (2006) Weather summary during pilot experiment of severe thunderstorms-observations and regional modeling (STORM) programme-2006 (13 April to 31 May, 2006). Department of Science and Technology, Government of India, Technology Bhawan, New Delhi

39. Mohapatra M, Mohanty UC (2004) Some characteristics of low pressure systems and summer monsoon rainfall over Orissa. Curr Sci 87(9):1245-1255

40. Ommi A, Emami F, Zíková N, Hopke PK, Begum BA (2017) Trajectory-based models and remote sensing for biomass burning assessment in Bangladesh. Aerosol Air Qual Res 17(2):465-475

41. Pant P, Baker SJ, Guttikunda S, Goel A, Shukla A, Harrison RM (2016) Analysis of size-segregated winter season aerosol data from New Delhi, India. Atmos Pollut. Res 7:100-109

42. Papanastasiou DK, Melas D (2009) Climatology and impact on air quality of sea breeze in an urban coastal environment. Int J Climatol 29(2):305-315

43. Parkhi N, Chate D, Ghude SD, Peshin S, Mahajan A, Srinivas R, Surendran D, Ali K, Singh S, Trimbake H, Beig G (2016) Large inter annual variation in air quality during the annual festival 'Diwali' in an Indian megacity. J Environ Sci 43:265-272

44. Ramachandran S, Ghosh S, Verma A, Panigrahi PK (2013) Multiscale periodicities in aerosol optical depth over India. Environ Res Lett 8(014034):8

45. Rolph GD (2016) Real-time environmental applications and display system (READY) website. NOAA Air Resources Laboratory, Silver Spring. http://ready.arl.noaa.gov

46. Saha U, Talukdar S, Jana S, Maitra A (2014) Effects of air pollution on meteorological parameters during Deepawali festival over an Indian urban metropolis. Atmos Environ 98:530-539

47. Sahu SK, Beig G, Neha P (2011) Anthropogenic emission of PM2.5 and PM10 for air quality forecasting during commonwealth games 2010 Delhi. Atmos Environ 45:6180-6190

48. Sahu SK, Ohara T, Beig G (2017) The role of coal technology in defining India's climate change agents and other pollutants. Environ Res Lett ERL 12:105006

49. Sati AP, Mohan M (2014) Analysis of air pollution during a severe smog episode of November 2012 and the Diwali Festival over Delhi, India. Int J Remote Sens 35(19):6940-6954

50. Singh J, Noh YJ, Agrawal S, Tyagi B (2018) Dust detection and aerosol properties over Arabian Sea using MODIS data. Earth Syst Environ. https://doi.org/10.1007/s41748-018-0079-1

51. Smart Cities Mission (2017) http://smartcities.gov.in/content/ 
52. Stein AF, Draxler RR, Rolph GD, Stunder BJB, Cohen MD, Ngan F (2015) NOAA's HYSPLIT atmospheric transport and dispersion modeling system. Bull Am Meteorol Soc 96:2059-2077. https:// doi.org/10.1175/BAMS-D-14-00110.1

53. Stull RB (1988) An introduction to boundary layer meteorology. Kluwer Academic, Dordrecht, p 521

54. Su L, Yuan Z, Fung JCH, Lau AKH (2015) A comparison of HYSPLIT backward trajectories generated from two GDAS datasets. Sci Total Environ 506-507:527-537

55. Swain D, Roberts GJ, Dash J, Lekshmi K, Vinoj V, Tripathy S (2017) Impact of rapid urbanization on the city of Bhubaneswar, India. Proc Natl Acad Sci India Sect A 87(4):845-853

56. Torrence C, Compo GP (1998) A practical guide to wavelet analysis. Bull Am Meteorol Soc 79:61-78

57. Tyagi B, Satyanarayana ANV (2015) Delineation of surface energy exchanges variations during thunderstorm and non-thunderstorm days during pre-monsoon season. J Atmos Solar-Terr Phys 122:138-144

58. Tyagi B, Satyanarayana ANV, Rajvanshi RK, Mandal M (2014) Surface energy exchanges during pre-monsoon thunderstorm activity over a tropical station Kharagpur. Pure Appl Geophys 171(7):1445-1459
59. Vukovich FM (1997) Time scales of surface ozone variations in the regional, non-urban environment. Atmos Environ 31(10):1513-1530. https://doi.org/10.1016/S1352 $-2310(96) 00279-8$

60. Xing YF, Xu YH, Shi MH, Lian YX (2016) The impact of $\mathrm{PM}_{25}$ on the human respiratory system. J Thorac Dis 8(1):E69

61. Xu X, Akhtar US (2010) Identification of potential regional sources of atmospheric total gaseous mercury in Windsor, Ontario, Canada using hybrid receptor modeling. Atmos Chem Phys 10:7073-7083

62. Zeri M, Carvalho VSB, Cunha-Zeri G, Oliveira-Junior JF, Lyra GB, Freitas ED (2016) Assessment of the variability of pollutants concentration over the metropolitan area of Sao Paulo, Brazil, using the wavelet transform. Atmos Sci Lett 17:87-95

63. Zhang YL, Cao F (2015) Fine particulate matter (PM2.5) in China at a city level. Sci Rep 5:14884

Publisher's Note Springer Nature remains neutral with regard to jurisdictional claims in published maps and institutional affiliations. 